\title{
Psychiatry
}

\section{Association of the HTR2A T102C SNP with Weight Gain and Changes in Biochemical Markers in Patients Receiving Antipsychotics}

\author{
Mikhail Yu. Tolmachev ${ }^{1}$; Liliya Sch. Akhmetova ${ }^{2}$; Natalia A. Shnayder, PhD, ScD ${ }^{1}$; \\ Evgeny E. Ershov ${ }^{1,3}$; Alexander V. Bugorsky ${ }^{3}$; Vladimir V. Kravtsov ${ }^{1,4}$; Anastasia E. \\ Taraskina, $\mathrm{PhD}^{1}$; Boris V. Andreev, $\mathrm{PhD}, \mathrm{ScD}^{4}$; Kausar K. Yakhin, $\mathrm{PhD}, \mathrm{ScD}^{5}$; \\ Nikolay G. Neznanov, PhD, $\mathrm{ScD}^{1}$; Regina F. Nasyrova, $\mathrm{PhD}, \mathrm{ScD}^{13^{*}}$ \\ ${ }^{I}$ V.M. Bekhterev National Medical Research Centre for Psychiatry and Neurology, St. Petersburg, Russia \\ ${ }^{2}$ V.M. Bekhterev Republican Clinical Psychiatric Hospital, Kazan, Russia \\ ${ }^{3}$ P.P. Kashchenko Psychiatric Hospital №1, St. Petersburg, Russia \\ ${ }^{4}$ Saint-Petersburg State University, St. Petersburg, Russia \\ ${ }^{5}$ Kazan State Medical University, Kazan, Russia
}

\begin{abstract}
The purpose of our research was to study the association of the HTR2A T102C (rs6313) SNP with anthropometric and biochemical markers in patients treated with typical and atypical antipsychotics in monotherapy mode.

Materials and methods: One hundred and seventeen white inpatients (95 men and 22 women) with F2 disorders (ICD-10, 1995) were enrolled in the study. All patients were divided into two groups by the antipsychotic class with which they were treated (Group 1 included 40 patients treated with typical antipsychotics; Group 2 included 77 patients treated with atypical antipsychotics) and two subgroups by weight change criteria during the study (Subgroup 1 included patients with weight change $>6 \%$; Subgroup 2 included patients with weight change $<6 \%$ ). The following examinations were performed: physical examination, anthropometric measurements (BMI. WC, TC), clinical examination, blood test, and genotyping for the HTR2A T102C (rs6313) SNP.

Results: There were no statistically significant differences in the distribution of genotypes of the HTR2A T102C (rs6313) SNP between Group 1 and Group $2(P>0.05)$. Kruskal-Wallis one-way analysis of variance between subgroups showed statistically significant differences between carbamide levels in the second visit in Group $2(P=0.02)$. We showed statistically significant differences between TT and CT genotypes of the HTR2A T102C SNP: carbamide level was greater in TT carriers $(P=0.02)$. The strength of associations and risks between alleles of the HTR2A T102C SNP and antipsychotic-induced weight change were as follows: $\mathrm{OR}_{\mathrm{C}}=0.49 ; \mathrm{CI}_{\mathrm{C}}[0.25 ; 0.95] ; \mathrm{RR}_{\mathrm{C}}=0.58 \mathrm{CI}_{\mathrm{C}}[0.35 ; 0.97] ; \mathrm{OR}_{\mathrm{T}}=2.03 ; \mathrm{CI}_{\mathrm{T}}[1.05 ; 3.94] ; \mathrm{RR}_{\mathrm{T}}=1.7 \mathrm{CI}_{\mathrm{T}}[1.02 ; 2.81]$.

Conclusion: Our results of the pilot pharmacogenetic studies show an association of the T allele carriage of the HTR2A T102C (rs6313) SNP with risk of antipsychotic-induced weight gain. The continuation of this study and an increase in the sample size will allow establishing valid pharmacogenetic markers for the risk of antipsychotic-induced weight gain. (International Journal of Biomedicine. 2018;8(3):186-191.)
\end{abstract}

Key Words: antipsychotics $\bullet$ single nucleotide polymorphism $\bullet$ serotonin receptor $2 \mathrm{~A} \bullet H T R 2 A$ gene $\bullet$ weight gain

\section{Abbreviations}

FPG, fasting plasma glucose; FGAs, first-generation antipsychotics; HWE, Hardy-Weinberg equilibrium; HDL-C, high-density lipoprotein cholesterol; LDL-C, low-density lipoprotein cholesterol; MetS, metabolic syndrome; SGAs, second-generation antipsychotics; SNP, single nucleotide polymorphism; TC, total cholesterol; VLDL-C, very-low-density lipoprotein cholesterol.

\section{Introduction}

Dysfunction of the dopamine system has been known to underlie the pathophysiology of schizophrenia since the 1960s. FGAs, especially high potency drugs such as haloperidol, mainly bind to D2 receptors..$^{(1-3)}$ All SGAs tightly bind to serotonin (5-hydroxytryptamine, 5-HT) receptor $2 \mathrm{~A}$ relative to the dopamine $\mathrm{D} 2$ receptor, and this 
was once thought to be one of the defining characteristics of "atypicality" of SGAs. ${ }^{(1)}$ In general, atypical agents have an enhanced 5-HT2A/D2 affinity ratio and that helps explain why typical and atypical agents may have different clinical effects. ${ }^{(4)}$ The atypical antipsychotics generally have additional affinities for a variety of neurotransmitter receptor subtypes (serotonergic, dopaminergic, histaminergic, adrenergic, and muscarinic acetylcholine receptor). ${ }^{(5)}$ FGAs are characterized by extrapyramidal symptoms, and hyperprolactinemia and, to a lesser extent, metabolic disorders; SGAs are more associated with weight gain, the appearance of type 2 diabetes, cardiovascular diseases, and the development of MetS..$^{(6,7)}$ Results of numerous studies show that antipsychotic induced weight gain occurs in 12-16 weeks. ${ }^{(8)}$ It was found that patients with psychotic disorders are more likely to suffer from obesity than the general population. ${ }^{(9)}$ Epidemiological studies have shown that patients with schizophrenia are 2.5 times more likely to die from cardiovascular complications and their estimated life span is $20 \%$ less than the general population. ${ }^{(10)}$ The receptor antagonism at the central level of regulation, caused by taking antipsychotics, provokes an increased appetite and reduced possibility of feeling sated. ${ }^{(11)}$

5-HT2A is one of the most abundantly expressed serotonin receptors in the brain, with high levels in the cerebral cortical areas, hippocampus, nucleus accumbens, and caudate nucleus. ${ }^{(10)}$ This receptor belongs to G-proteincoupled receptors and is the primary excitatory receptor of serotonin, mainly acting at post-synaptic neurons. The 5-HT2A receptor gene (HTR2A) is located on chromosome 13(13q14.2). The expression of HTR2A is regulated by several functional polymorphisms, ${ }^{(13,14)}$ among which T102C (rs6313) is the most studied SNP in the gene. Compared with the T allele, the $\mathrm{C}$ allele leads to lower receptor expressions ${ }^{(13)}$ and lower receptor binding potentials, ${ }^{(15)}$ and therefore reduces excitation at post-synaptic neurons. ${ }^{(16)}$ Significant association between the HTR2A T102C (rs6313) SNP and antipsychotic weight gain was found during treatment with olanzapine and risperidone in Japanese and Chinese populations. ${ }^{(17)}$

The purpose of our research was to study the association of the HTR2A T102C (rs6313) SNP with anthropometric and biochemical markers in patients treated with typical and atypical antipsychotics in monotherapy mode.

\section{Materials and Methods}

\section{Participants}

One hundred and seventeen white inpatients $(95$ men and 22 women) with ICD-10 Diagnosis Codes F20 (92/79\%), F20.2 (1/0.85\%), F20.6 (3/2.6\%), F20+F10.2 (2/1.7\%), F21.8 (2/1.7\%), F22.8 (3/2.6\%), F23 (6/5.1\%), F23.1 (3/2.6\%), and F25.1(4/3.4\%) were enrolled in the study. Mean age of the disease onset was $24.56 \pm 1.95$ years; mean age of the first medical help was $26.5 \pm 1.65$ years; mean age of the first antipsychotic therapy was $25.7 \pm 1.7$ years. The period of participation in the study was $8.36 \pm 1.13$ weeks. Drugs taken by the patients are presented in Table 1.

All patients were divided into two groups (Table 2) by the antipsychotic class with which they were treated (Group 1 included 40 patients treated with typical antipsychotics; Group 2 included 77 patients treated with atypical antipsychotics) and two subgroups (Table 3 ) by weight change criteria during the study (Subgroup 1 included patients with weight change $>6 \%$; Subgroup 2 included patients with weight change $<6 \%$ ).

\section{Table 1}

\section{Drugs taken by the patients in the study}

\begin{tabular}{|l|c|l|c|}
\hline \multicolumn{2}{|c|}{ Typical antipsychotics } & \multicolumn{2}{c|}{ Atypical antipsychotics } \\
\hline \multicolumn{1}{|c|}{ Drug } & Frequency (\%) & \multicolumn{1}{c|}{ Drug } & Frequency (\%) \\
\hline Haloperidol & $28(70)$ & Olanzapine & $15(19.5)$ \\
\hline Zuclopenthixol & $6(15)$ & Risperidone & $17(22.1)$ \\
\hline Triphtazinum & $6(15)$ & Quetiapine & $12(15.6)$ \\
\hline & & Asenapine & $5(6.5)$ \\
\hline & & Clozapine & $11(14.2)$ \\
\hline & & Paliperidone & $6(7.8)$ \\
\hline & & Aripiprazole & $3(3.9)$ \\
\hline & & Sertindole & $5(6.5)$ \\
\hline & & Sulpiride & $1(1.3)$ \\
\hline & & Amisulpride & $1(1.3)$ \\
\hline & & Aminasine & $1(1.3)$ \\
\hline
\end{tabular}

Table 2

The distribution of patients by the antipsychotic drugs

\begin{tabular}{|l|c|c|c|c|}
\hline \multirow{2}{*}{ Patients } & \multicolumn{2}{|c|}{ Group 1 } & \multicolumn{2}{c|}{ Group 2 } \\
\cline { 2 - 5 } & $\mathrm{n}$ & $\%$ & $\mathrm{n}$ & $\%$ \\
\hline Total & 40 & 34.1 & 77 & 65.9 \\
\hline Male & 29 & 72.5 & 66 & 85.7 \\
\hline Female & 11 & 27.5 & 11 & 14.3 \\
\hline
\end{tabular}

Table 3.

The distribution of patients by weight change criteria during the study

\begin{tabular}{|c|c|c|c|c|c|c|}
\hline \multirow[b]{2}{*}{ Variable } & \multicolumn{2}{|c|}{ Group 1} & \multicolumn{2}{|c|}{ Group 2} & \multirow[b]{2}{*}{ ¿0 } & \multirow{2}{*}{$\begin{array}{c}\frac{0}{\pi} \\
\stackrel{\pi}{\pi} \\
2 \\
2\end{array}$} \\
\hline & $\begin{array}{c}\text { Subgroup } \\
1\end{array}$ & $\begin{array}{c}\text { Subgroup } \\
2\end{array}$ & $\underset{1}{\text { Subgroup }}$ & $\begin{array}{c}\text { Subgroup } \\
2\end{array}$ & & \\
\hline Sample size & 8 & 28 & 17 & 46 & 99 & 0.63 \\
\hline $\begin{array}{l}\text { Median age, } \\
\text { yrs }\end{array}$ & $\begin{array}{c}33.4 \\
(24.9 ; 41.09)\end{array}$ & $\begin{array}{c}34.1 \\
(29.9 ; 38.3)\end{array}$ & $\begin{array}{c}29.0 \\
(24.9 ; 33.1)\end{array}$ & $\begin{array}{c}35.1 \\
(32.1 ; 38.1)\end{array}$ & & 0. \\
\hline Gender $(\mathrm{M} / \mathrm{F})$ & $5 / 3$ & $20 / 8$ & $16 / 1$ & $39 / 7$ & 99 & 0.11 \\
\hline $\begin{array}{l}\text { Median period } \\
\text { of participation, } \\
\text { weeks }\end{array}$ & $\begin{array}{c}5.6 \\
(4.1 ; 7.1)\end{array}$ & $\begin{array}{c}7.2 \\
(5.9 ; 8.5)\end{array}$ & $\begin{array}{c}8.4 \\
(6.2 ; 10.4)\end{array}$ & $\begin{array}{c}9.2 \\
(6.8 ; 11.6)\end{array}$ & & 0.84 \\
\hline $\begin{array}{l}\text { Intake of } \\
\text { benzodiazepine } \\
\text { in anamnesis } \\
(\text { Yes/No) }\end{array}$ & $3 / 3$ & $9 / 13$ & $7 / 7$ & $20 / 9$ & 71 & 0.24 \\
\hline $\begin{array}{l}\text { Smoking (Yes/ } \\
\text { No) }\end{array}$ & $5 / 3$ & $16 / 7$ & $8 / 8$ & $20 / 18$ & 85 & 0. \\
\hline
\end{tabular}




\section{Study design}

The research consisted of two visits: the first during enrollment in the study, the second when the observation was completed. All patients signed an informed consent document before enrolling in the project. The following examinations were performed: physical examination, anthropometric measurements (BMI. WC, TC), clinical examination, blood test (ALT, AST, FPG, VLDL-C, LDL-C, HDL-C, TC, triglycerides (TG), total protein, albumin, creatinine, uric acid, carbamide) and molecular-genetic evaluation. Genomic DNA was isolated from peripheral leukocytes with "Hemolytic" reagent (InterLabService, Russian Federation) for pre-processing of whole peripheral and umbilical blood and with extraction kit Ribo-prep (InterLabService, Russian Federation).Genotyping for the HTR2A T102C (rs6313) SNP was performed using realtime PCR by the RotorGene 6000 (Quagen, Germany) with an HTR2A kit according to the manufacturer's protocol (Syntol, tge Russian Federation).

\section{Statistical Analysis}

Descriptive statistics were used to summarize the data. Shapiro - Wilk test was used for normality test. Chi-square and Fisher's exact tests were used to determine the association between categorical measure including allele and genotype. $\mathrm{T}$ test or paired $\mathrm{T}$ test were used for comparison between two groups with a normal distribution of the quantitative characteristic. Wilcox test or paired Wilcox test were used as nonparametric alternative. Analysis of variance and Tukey post hoc test were used for comparison between 3 groups with a normal distribution of the quantitative characteristic and homogeneous dispersion (established by Levene test). Kruskal - Wallis one-way analysis of variance and Dunn post hoc test with Bonferroni adjustment were nonparametric alternative. Correlation was measured with Spearman rank correlation coefficient. The strength of the associations was expressed as odds ratio (OR) with $95 \%$ confidence interval (CI) and $95 \%$ credible interval $(\mathrm{CrI})$, relative risk was expressed as risk ratio (RR). Binomial logistic model was also performed. The quality of the model (Area under the curve (AUC) specificity and sensitivity) was measured by receiver operating characteristic (ROC) analysis. For all tests, a probability value of $P<0.05$ was considered statistically significant. Statistical analysis was performed by $\mathrm{R}$ programming language with IDE Rstudio. LePAC. Three exact probability tests for departure from HWE due to heterozygote excess, heterozygote deficit and omnibus probability test were carried out using GENEPOP (v. 4.7.0)

\section{Results and Discussion}

There were no statistically significant differences in the distribution of genotypes of the HTR2A T102C (rs6313) SNP between Group 1 and Group $2(P>0.05)$ (Table 4). It was not possible to reject HWE because of heterozygote excess $(P=0.02)$. Dynamics of the biochemical markers is shown in Tables 5 and 6 ( $P$ value for differences between the first and second visits in whole group).

Kruskal-Wallis one-way analysis of variance between subgroups showed statistically significant differences between carbamide levels in the second visit in Group $2(P=0.02)$ (Tables 5 and 6). A Dunn post hoc test with Bonferroni adjustment showed statistically significant differences between TT and CT genotypes of the HTR2A T102C (rs6313) SNP: carbamide level was greater in TT carriers $(P=0.02)$.

Table 4.

Genotype distribution in the groups

\begin{tabular}{|l|c|c|c|c|c|}
\hline \multirow{2}{*}{ Group } & \multicolumn{3}{|c|}{ Genotype } & \multicolumn{2}{c|}{ Allele } \\
\cline { 2 - 6 } & $\mathrm{CC}$ & $\mathrm{CT}$ & $\mathrm{TT}$ & $\mathrm{T}$ & $\mathrm{C}$ \\
\hline \multirow{2}{*}{ Group 1 } & 6 & 28 & 6 & 40 & 40 \\
& $(5.12 \%)$ & $(23.93 \%)$ & $(5.12 \%)$ & $(17.0 \%)$ & $(17.0 \%)$ \\
\hline Group 2 & 11 & 49 & 17( & 83 & 71 \\
& $(9.4 \%)$ & $(41.9 \%)$ & $14.52 \%)$ & $(36.0)$ & $(30.0 \%)$ \\
\hline Fisher exact test & \multicolumn{3}{c|}{$P=0.70$} \\
\hline
\end{tabular}

Table 5.

Summarize data in Group 1, Me $\left(Q_{25} ; Q_{75}\right)$

\begin{tabular}{|c|c|c|c|c|c|}
\hline \multirow{2}{*}{\multicolumn{2}{|c|}{ Variable }} & \multicolumn{3}{|c|}{ Genotype } & \multirow{2}{*}{$\begin{array}{l}\frac{0}{3} \\
\frac{\pi}{7} \\
1 \\
0\end{array}$} \\
\hline & & $\mathrm{CC}$ & $\mathrm{CT}$ & TT & \\
\hline \multirow{2}{*}{$\begin{array}{l}\text { Weight, } \\
\mathrm{kg}\end{array}$} & $\mathrm{FV}$ & $60.8(59.2 ; 79.9)$ & $68.5(62.2 ; 81.8)$ & $79(66.2 ; 86.6)$ & \multirow{2}{*}{0.7} \\
\hline & SV & $60.0(56 ; 83)$ & $71(61 ; 80)$ & $77.4(70.7 ; 86.6)$ & \\
\hline \multirow{2}{*}{$\begin{array}{l}\mathrm{FPG}, \\
\mathrm{mmol} / \mathrm{L}\end{array}$} & $\mathrm{FV}$ & $5.17(5.11 ; 5.24)$ & $4.96(4.66 ; 5.48)$ & $5.61(5.12 ; 6.1)$ & \multirow{2}{*}{0.5} \\
\hline & SV & $\mid 5.61(4.87 ; 5.89)$ & $4.84(4.57 ; 5.19)$ & $4.89(4.68 ; 5.31)$ & \\
\hline \multirow{2}{*}{$\begin{array}{l}\mathrm{TC}, \\
\mathrm{mmol} / \mathrm{L}\end{array}$} & $\mathrm{FV}$ & $3.98(3.69 ; 4.18)$ & $4.84(4.37 ; 5.26)$ & $4.42(4.06 ; 4.60)$ & \multirow{2}{*}{0.6} \\
\hline & SV & $3.18(3.06 ; 4.28)$ & $4.51(4.24 ; 5.20)$ & $4.47(3.75 ; 4.57)$ & \\
\hline \multirow{2}{*}{$\begin{array}{l}\mathrm{TG}, \\
\mathrm{mmol} / \mathrm{L}\end{array}$} & $\mathrm{FV}$ & $|0.68(0.63 ; 1.06)|$ & $1.47(1.02 ; 1.90)$ & $1.59(1.19 ; 1.74)$ & \multirow{2}{*}{0.1} \\
\hline & SV & $|0.73(0.69 ; 1.00)|$ & $1.23(0.95 ; 1.55)$ & $1.52(1.49 ; 1.58)$ & \\
\hline \multirow{2}{*}{$\begin{array}{l}\text { VLDL-C, } \\
\mathrm{mmol} / \mathrm{L}\end{array}$} & $\mathrm{FV}$ & $0.31(0.28 ; 0.48)$ & $0.53(0.45 ; 0.71)$ & $0.62(0.55 ; 0.68)$ & \multirow{2}{*}{0.2} \\
\hline & SV & $0.33(0.31 ; 0.45)$ & $0.54(0.35 ; 0.58)$ & $0.46(0.54 ; 0.62)$ & \\
\hline \multirow{2}{*}{$\begin{array}{l}\mathrm{LDL}-\mathrm{C} \\
\mathrm{mmol} / \mathrm{L}\end{array}$} & $\mathrm{FV}$ & $2.30(2.22 ; 3.10)$ & $2.90(2.55 ; 3.57)$ & $2.66(2.43 ; 3.20)$ & \multirow{2}{*}{0.1} \\
\hline & SV & $\mid 1.65(1.59 ; 2.63)$ & $2.74(2.48 ; 3.62)$ & $2.85(1.92 ; 3.12)$ & \\
\hline \multirow{2}{*}{$\begin{array}{l}\text { HDL-C, } \\
\mathrm{mmol} / \mathrm{L}\end{array}$} & $\mathrm{FV}$ & $1.20(0.95 ; 1.46)$ & $1.14(0.9 ; 1.24)$ & $0.77(1.01 ; 1.16)$ & \multirow{2}{*}{0.6} \\
\hline & SV & $\mid 1.20(1.07 ; 1.20)$ & $1.10(0.94 ; 1.22)$ & $0.98(0.75 ; 1.06)$ & \\
\hline \multirow{2}{*}{$\begin{array}{l}\text { ALT, } \\
\mathrm{u} / \mathrm{L}\end{array}$} & $\mathrm{FV}$ & $16(14 ; 20)$ & $24.0(18.4 ; 40.6)$ & $17.5(13 ; 30.17$ & \multirow{2}{*}{0.03} \\
\hline & SV & $14(9 ; 18)$ & $25.0(18.3 ; 28.6)$ & $15.85(12.75 ; 28.1)$ & \\
\hline \multirow{2}{*}{$\begin{array}{l}\text { AST, } \\
\mathrm{u} / \mathrm{L}\end{array}$} & $\mathrm{FV}$ & $26(22 ; 29)$ & $31.0(22.7 ; 42.8)$ & $20.95(18.7 ; 44.1)$ & \multirow{2}{*}{0.004} \\
\hline & SV & $17(16 ; 19)$ & $23.3(18.7 ; 30.2)$ & $20.8(18.15 ; 23.07)$ & \\
\hline \multirow{2}{*}{$\begin{array}{l}\text { Albumin, } \\
\mathrm{g} / \mathrm{L}\end{array}$} & $\mathrm{FV}$ & $51.0(48.0 ; 51.1)$ & $47.0(44.9 ; 48.6)$ & $48.8(46.87 ; 50.5)$ & \multirow{2}{*}{0.84} \\
\hline & SV & $48(45.5 ; 53.5)$ & $47.0(44.5 ; 49.8)$ & $51.0(48.27 ; 52.75)$ & \\
\hline \multirow{2}{*}{$\begin{array}{l}\text { Total } \\
\text { protein, } \\
\mathrm{g} / \mathrm{L}\end{array}$} & $\mathrm{FV}$ & $77(76 ; 82)$ & 73.0(69.75;76.9) & $73.8(72.4 ; 75.57)$ & \multirow{2}{*}{0.3} \\
\hline & SV & $73(71 ; 75)$ & 71.0(68.7;75.2) & $74.55(71.52 ; 75.07)$ & \\
\hline \multirow{2}{*}{$\begin{array}{l}\text { Carba- } \\
\text { mide, } \\
\mathrm{mmol} / \mathrm{L}\end{array}$} & $\mathrm{FV}$ & $3.80(2.80 ; 3.90)$ & $3.45(3.11 ; 3.91)$ & $3.99(3.38 ; 4.39)$ & \multirow{2}{*}{0.4} \\
\hline & SV & $\mid 3.00(2.60 ; 4.00)$ & $3.74(2.95 ; 4.23)$ & $3.79(3.45 ; 4.13)$ & \\
\hline
\end{tabular}

$\mathrm{FV}$ - the first visit, $\mathrm{SV}$ - the second visit 


\section{Table 6}

Summarize data in Group 2, Me $\left(Q_{25} ; Q_{75}\right)$

\begin{tabular}{|c|c|c|c|c|c|}
\hline \multirow{2}{*}{\multicolumn{2}{|c|}{ Variable }} & \multicolumn{3}{|c|}{ Genotype } & \multirow{3}{*}{$\begin{array}{l}\stackrel{0}{J} \\
\frac{\pi}{7} \\
\overbrace{}^{\prime}\end{array}$} \\
\hline & & $\mathrm{CC}$ & $\mathrm{CT}$ & TT & \\
\hline \multirow{2}{*}{$\begin{array}{l}\text { Weight, } \\
\mathrm{kg}\end{array}$} & $\mathrm{FV}$ & $72.1(69.4 ; 84)$ & $69.3(62.0 ; 81.1)$ & $73(62 ; 77)$ & \\
\hline & SV & $74.0(71.2 ; 84.5)$ & $72.5(62.5 ; 82.0)$ & $75.5(67.3 ; 77.9)$ & 0.004 \\
\hline \multirow{2}{*}{$\begin{array}{l}\mathrm{FPG}, \\
\mathrm{mmol} / \mathrm{L}\end{array}$} & $\mathrm{FV}$ & 5.69(5.48; & $5.30(4.87 ; 5.68)$ & $5.40(5.0$ & \multirow{2}{*}{0.01} \\
\hline & SV & $5.18(4.85 ; 5.31)$ & $5.14(4.66 ; 5.5)$ & $4.884 .47 ; 5.27)$ & \\
\hline \multirow{2}{*}{$\begin{array}{l}\mathrm{TC}, \\
\mathrm{mmol} / \mathrm{L}\end{array}$} & $\mathrm{FV}$ & $4.33(3.9$ & $4.75(4.0$ & 4.44 & \multirow{2}{*}{0.99} \\
\hline & SV & $4.50(4.13 ; 5.18)$ & $4.82(4.20 ; 5.48)$ & $4.86(3.64 ; 5.42)$ & \\
\hline \multirow{2}{*}{$\begin{array}{l}\mathrm{TG}, \\
\mathrm{mmol} / \mathrm{L}\end{array}$} & $\mathrm{FV}$ & $1.39(1.16 ; 1.54)$ & $1.39(1.07 ; 1.95)$ & 1.361 .0 & \multirow{2}{*}{0.1} \\
\hline & SV & $1.82(1.17 ; 2.02)$ & $1.57(0.96$ & $1.5\left(1.0^{\prime}\right.$ & \\
\hline \multirow{2}{*}{$\begin{array}{l}\text { VLDL-C, } \\
\mathrm{mmol} / \mathrm{L}\end{array}$} & $\mathrm{FV}$ & $0.53(0.45 ; 0.54)$ & $0.5(0.41 ; 0.61)$ & $0.49(0.34 ; 0.69)$ & \multirow{2}{*}{0.1} \\
\hline & SV & $0.53(0.40 ; 0.67)$ & $0.52(0.35 ; 0.73)$ & $0.59(0.43 ; 1.57)$ & \\
\hline \multirow{2}{*}{$\begin{array}{l}\text { LDL-C, } \\
\mathrm{mmol} / \mathrm{L}\end{array}$} & $\mathrm{FV}$ & $2.56(2.10 ; 2.98)$ & $2.95(2.37 ; 3.58)$ & $2.55(2.01 ; 3.65)$ & \multirow{2}{*}{0.8} \\
\hline & SV & $3.04(2.46 ; 3.44)$ & $2.93(2.67 ; 3.60)$ & $2.99(2.5$ & \\
\hline \multirow{2}{*}{$\begin{array}{l}\text { HDL-C, } \\
\mathrm{mmol} / \mathrm{L}\end{array}$} & $\mathrm{FV}$ & $1.30(1.00 ; 1.56)$ & $1.19(0 . S$ & $0)$ & \multirow{2}{*}{0.5} \\
\hline & SV & $0.96(0.91 ; 1.05)$ & $1.15(0.95 ; 1.32)$ & $1.26(1.07 ; 1.40)$ & \\
\hline \multirow{2}{*}{$\begin{array}{l}\text { ALT, } \\
\mathrm{u} / \mathrm{L}\end{array}$} & $\mathrm{FV}$ & 32.45 & $22.4(16.0 ; 30.3)$ & $25.2(17.7 ; 3$ & \multirow{2}{*}{0.8} \\
\hline & SV & 31.2 & $22.55(14.47$ & 23. & \\
\hline \multirow{2}{*}{$\begin{array}{l}\text { AST, } \\
\mathrm{u} / \mathrm{L}\end{array}$} & $\mathrm{FV}$ & $38.0(27.77 ; 45.05)$ & $28.5(21.0 ; 35.2)$ & $27.0(23.8 ; 31.0)$ & \multirow{2}{*}{0.4} \\
\hline & SV & $26.0(18.25 ; 33.5)$ & $24.5(21.75 ; 35.55)$ & $21.0(19.5 ; 30.65)$ & \\
\hline \multirow{2}{*}{$\begin{array}{l}\text { Albumin, } \\
\mathrm{g} / \mathrm{L}\end{array}$} & $\mathrm{FV}$ & $50.2(46.6 ; 50.9)$ & $48.4(46.0 ; 50.5)$ & $47.0(46.45 ; 49.40)$ & \multirow{2}{*}{0.2} \\
\hline & SV & $47.1(45.95 ; 48.1)$ & $48.6(45.4 ; 50.7)$ & $50.1(48.07 ; 50.5)$ & \\
\hline \multirow{2}{*}{$\begin{array}{l}\text { Total } \\
\text { protein, } \\
\mathrm{g} / \mathrm{L}\end{array}$} & $\mathrm{FV}$ & 75.6(73.2;76.07) & $73.5(70.0 ; 77.0)$ & $72.55(70.02 ; 79.00)$ & \multirow{2}{*}{0.7} \\
\hline & SV & $77.0(72.05 ; 77.50)$ & $72.8(69.37 ; 77.25)$ & $71.85(69.55 ; 74.75)$ & \\
\hline \multirow{2}{*}{$\begin{array}{l}\text { Carba- } \\
\text { mide, } \\
\mathrm{mmol} / \mathrm{L}\end{array}$} & $\mathrm{FV}$ & $4.29(3.45$ & $3.90(3.35 ; 4.30)$ & $3.80(3.40 ; 4.1)$ & \multirow{2}{*}{0.4} \\
\hline & SV & $4.0(3.74 ; 4.21)$ & $3.8(3.48 ; 4.40)$ & $4.75(4.35 ; 5.17)$ & \\
\hline
\end{tabular}

$F V$ - the first visit, SV-the second visit

Triglyceride levels in the second visit were correlated with LDL-C $(P=0.9)$, HDL-C $(\mathrm{r}=0.8)$, and VLDL-C ( $\mathrm{r}=0.9)$ levels in the first visit, and with glucose $(\mathrm{r}=0.84)$ and VLDL-C $(\mathrm{r}=0.9)$ levels in the second visit; TC levels in the second visit were correlated with LDL-C levels in the second visit ( $\mathrm{r}=0.91)$.

The strength of associations and risks between alleles of the HTR2A T102C SNP and antipsychotic-induced weight change were as follows: $\mathrm{OR}_{\mathrm{C}}=0.49 ; \mathrm{CI}_{\mathrm{C}}[0.25 ; 0.95] ; \mathrm{RR}_{\mathrm{C}}=0.58$ $\mathrm{CI}_{\mathrm{C}}[0.35 ; 0.97] ; \mathrm{OR}_{\mathrm{T}}=2.03 ; \mathrm{CI}_{\mathrm{T}}[1.05 ; 3.94] ; \mathrm{RR}_{\mathrm{T}}=1.7 \mathrm{CI}_{\mathrm{T}}[1.02$; 2.81]. In Bayesian statistics: $\mathrm{OR}_{\mathrm{C}}=0.499 . \mathrm{CrI}_{\mathrm{C}}=[0.256 ; 0.951]$; $\mathrm{OR}_{\mathrm{T}}=2.003 ; \mathrm{CrI}_{\mathrm{T}}=[1.052 ; 3.904]$. Fisher exact test: $P=0.04$.

We also performed a binomial logistic regression (Table 7), where the dependent variable was the binomial factor (weight change $>6 \%$ during research, Yes/No), and predictors were genotypes of the HTR2A T102C SNP and antipsychotics
(Haloperidol, Olanzapine, Risperidone, Quetiapine) and their daily dosage. The binomial logistic model was described by ROC analysis (Figure 1). Cutoff for specificity and sensitivity of the logistic model was 0.53 . At this level, specificity of the model was 0.80 and sensitivity of the model was 0.80 .

Table 7.

Binomial logistic regression coefficients

\begin{tabular}{|c|c|c|c|c|}
\hline Variable & Estimate & $\begin{array}{l}\text { Standard } \\
\text { Error }\end{array}$ & $\mathrm{z}$ value & $\operatorname{Pr}(>|z|)$ \\
\hline Intercept & 3.4518 & 2.7262 & 1.266 & 0.20 \\
\hline rs6313 CT & 2.6672 & 1.7791 & 1.499 & 0.13 \\
\hline rs6313 TT & 4.8865 & 2.4338 & 2.008 & $0.04 *$ \\
\hline Olanzapine & -2.7532 & 5.2068 & -0.529 & 0.59 \\
\hline Risperidone & 26.7116 & 4941.9003 & 0.005 & 0.99 \\
\hline Quetiapine & -4.8765 & 3.5435 & -1.376 & 0.16 \\
\hline Dosage (in all) & -0.6655 & 0.3143 & -2.118 & $0.03 *$ \\
\hline Dosage of Olanzapine & 0.3208 & 0.5887 & 0.545 & 0.58 \\
\hline Dosage of Risperidone & -7.9641 & 1235.4747 & -0.006 & 0.99 \\
\hline Dosage of Quetiapine & 0.6660 & 0.3149 & 2.115 & $0.03 *$ \\
\hline \multicolumn{5}{|c|}{$\begin{array}{l}\text { Signif. codes: } 0 \text { '***’0.001 ‘**’0.01 ‘*’0.05 ‘’0.1 '’1 } \\
\text { Null deviance: } 46.070 \text { on } 33 \text { degrees of freedom } \\
\text { Residual deviance: } 28.018 \text { on } 24 \text { degrees of freedom } \\
\text { AIC: } 48.018\end{array}$} \\
\hline
\end{tabular}

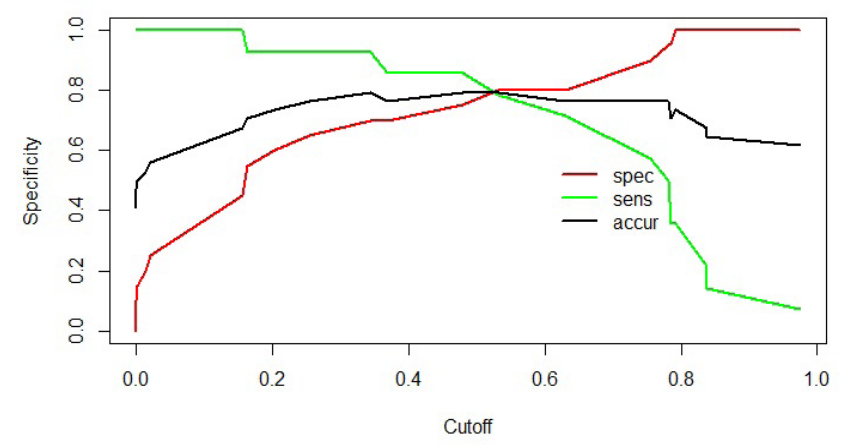

Fig. 1. $R O C$ analysis curve: $A U C=0.88 ;$ Concordance $=0.86$.

HWE was not observed in the prospective group, but it was observed $(P=0.34)$ in the population group $(n=229$ patients) with same inclusion criteria (except monotherapy mod). Our assumption is that heterozygotes carriers of the HTR2A T102C (rs6313) SNP are more stable in monotherapy and needed changes in therapy less often. We are going to increase the prospective sample size to get more information. Received results showed that different classes (FGAs, SGAs) provided different changes in biochemical markers and weight. Atypical antipsychotics led to statistically significant differences in body weight and glucose concentration, which are considered as pre-diabetic changes and could be part of MetS. Mechanisms of these changes are widely 
discussed. On the other hand, FGAs provided statistically significant differences in enzyme (AST, ALT) activity. We did not measure iso-enzymes of the hepatic fraction, so we cautiously put forward an assumption about hepatotoxicity of typical antipsychotics. TT genotype carriers of the HTR $2 \mathrm{~A}$ T102C (rs6313) SNP, who received atypical antipsychotics, had a higher concentration of carbamide. Carbamide is the chief nitrogenous end product and is dependent on protein intake. In another study, it was shown that the HTR2A T102C (rs6313) SNP affects food behavior and that TT carriers prefer high-protein food. ${ }^{(18)}$

Our study showed that the T allele carriers of the HTR $2 A$ T102C (rs6313) SNP have increased risk of antipsychoticinduced weight change. The intercept in our regression model consisted of the CC genotype of the HTR2A T102C (rs6313) SNP, haloperidol, and single dosage. Patients with the TT genotype of the HTR2A T102C (rs6313) SNP had significant differences in association with antipsychotic-induced weight change than CC carriers. Despite the synonymous substitution in this SNP, it can affect, by linkage, disequilibrium with the HTR2A $1438 \mathrm{~A} / \mathrm{G}$ SNP in the promoter region. ${ }^{(19)}$ Also, changing Haloperidol to Quetiapine leads to higher OR of antipsychotic-induced weight change, with a positive dosedependent effect (mean dose of $318.75 \mathrm{mg} /$ day). Similar results showed Brecher et al. (2007). Long-term treatment with quetiapine monotherapy was associated with moderate weight gain. Most weight gain occurs within the first 12 weeks of treatment and has no clear dose relationship. ${ }^{(20)}$

\section{Conclusion}

Our results of the pilot pharmacogenetic studies show an association of the $\mathrm{T}$ allele carriage of the HTR $2 A \mathrm{~T} 102 \mathrm{C}$ (rs6313) SNP with risk of antipsychotic-induced weight gain. The continuation of this study and an increase in the sample size will allow establishing valid pharmacogenetic markers for the risk of antipsychotic-induced weight gain.

\section{Competing interests} interests.

The authors declare that they have no competing

\section{Acknowledgments}

We would like to express our sincere appreciation to Oleg V. Limankin, PhD, ScD, the head of St. Petersburg State Budgetary Healthcare Institution "P. P. Kashchenko Psychiatric Hospital №1" (St. Petersburg, the Russian Federation) and Farit G. Ziganshin, MD, the head of State autonomous healthcare institution "V. M. Bekhterev Republican clinical psychiatric hospital" of the Ministry of Health of Tatarstan Republic (Kazan, the Russian Federation). We also thank Dr. Nikita Khromov-Borisov (Federal State Budgetary Institution "V. A. Almazov Federal North-West Medical Research Centre", St. Petersburg, the Russian Federation) for valuable suggestions and helping in the statistical analysis.

\section{References}

1. Zhang JP, Malhotra AK. Pharmacogenetics and antipsychotics: therapeutic efficacy and side effects prediction. Expert Opin Drug Metab Toxicol. 2011;7(1):9-37. doi: 10.1517/17425255.2011.532787.

2. Jones PB, Barnes TR, Davies L, Dunn G, Lloyd H, Hayhurst KP, et al. Randomized controlled trial of the effect on Quality of Life of second- vs first-generation antipsychotic drugs in schizophrenia: Cost Utility of the Latest Antipsychotic Drugs in Schizophrenia Study (CUtLASS 1). Arch Gen Psychiatry. 2006;63(10):1079-87.

3. Nasyrova RF, Ivanov MV, Neznanov NG. Introduction to psychopharmacogenetics. St. Petersburg; 2015. [In Russian]. 4. Kuroki T, Nagao N, Nakahara T. Neuropharmacology of second-generation antipsychotic drugs: a validity of the serotonin-dopamine hypothesis. Prog Brain Res. 2008;172:199-212. doi: 10.1016/S0079-6123(08)00910-2.

5. Horacek J, Bubenikova-Valesova V, Kopecek M, Palenicek T, Dockery C, Mohr P, Höschl C. Mechanism of action of atypical antipsychotic drugs and the neurobiology of schizophrenia. CNS Drugs. 2006;20(5):389-409.

6. Nasyrova RF, Tolmachev MY, Sychev DA, Yakhin KK, Neznanov NG. [Mechanisms of development of antipsychotic-induced metabolic disorders: pharmacogenetic aspect]. Bulletin of Siberian Medicine. 2017;16(4):30-41. doi: 10.20538/1682-0363-2017-4-30-41. [Article in Russian].

7. Lencz T, Robinson DG, Napolitano B, Sevy S, Kane JM, Goldman D, Malhotra AK. DRD2 promoter region variation predicts antipsychotic-induced weight gain in first episode schizophrenia. Pharmacogenet Genomics. 2010;20(9):569 72. doi: 10.1097/fpc.0b013e32833ca24b

8. Maslovskiǐ SIu, Kozlovskiǐ VL. [Antipsychotic-induced weight gain: the possibilities of pharmacological correction]. Zh Nevrol Psikhiatr Iim S S Korsakova. 2008;108:8:81-6. [Article in Russian].

9. Dickerson FB, Brown $\mathrm{CH}$, Kreyenbuhl, JA, Fang L, Goldberg RW, Wohlheiter K, Dixon LB. Obesity among individuals with serious mental illness. Acta Psychiatr Scand. 2006;113(4):306-13.

10. Haslam DW, James WP. Obesity. Lancet. 2005;366(9492):1197-209.

11. Reynolds GP, Kirk SL. Metabolic side effects of antipsychotic drug treatment - pharmacological mechanisms. Pharmacol Ther. 2010;125(1):169-79. doi: 10.1016/j. pharmthera.2009.10.010.

12. Barnes NM, SharpT. A review of central 5-HT receptors and their function. Neuropharmacology. 1999;38(8):1083-152. 13. Polesskaya OO, Sokolov BP. Differential expression of the "C" and " $\mathrm{T}$ " alleles of the 5-HT2A receptor gene in the temporal cortex of normal individuals and schizophrenics. J Neurosci Res. 2002;67:812-22.

14. Myers RL, Airey DC, Manier DH, Shelton RC, SandersBush E. Polymorphisms in the regulatory region of the human serotonin 5-HT2A receptor gene (HTR2A) influence gene expression. Biol Psychiatry. 2007;61(2):167-73.

*Corresponding author: Regina F. Nasyrova, PhD, ScD; V. M. Bekhterev National Medical Research Centre for Psychiatry and Neurology, St. Petersburg, Russia.E-mail: reginaf@,bekhterev.ru 
15. Turecki G, Brière $R$, Dewar $K$, Antonetti $T$, Lesage AD, Séguin M, et al. Prediction of level of serotonin 2A receptor binding by serotonin receptor $2 \mathrm{~A}$ genetic variation in postmortem brain samples from subjects who did or did not commit suicide. Am J Psychiatry. 1999;156(9): 1456-8.

16. Aghajanian GK, Marek GJ. Serotonin induces excitatory postsynaptic potentials in apical dendrites of neocortical pyramidal cells. Neuropharmacology. 1997;36(4-5):589-99. 17. Lane HY, Liu YC, Huang CL, Chang YC, Wu PL, Lu CT, Chang WH. Risperidone-related weight gain: genetic and nongenetic predictors. J Clin Psychopharmacol. 2006;26(2):128-34.
18. Prado-Lima PS, Cruz IB., Schwanke CH, Netto CA, Licinio J. Human food preferences are associated with a 5-HT(2A) serotonergic receptor polymorphism. Mol Psychiatry. 2006;11(10):889-91.

19. Parsons MJ, D'Souza UM, Arranz MJ, Kerwin RW, Makoff AJ. The $-1438 \mathrm{~A} / \mathrm{G}$ polymorphism in the 5-hydroxytryptamine type $2 \mathrm{~A}$ receptor gene affects promoter activity. Biol Psychiatry. 2004;56(6):406-10.

20. Brecher M, Leong RW, Stening G, Osterling-Koskinen L, Jones AM. Quetiapine and long-term weight change: a comprehensive data review of patients with schizophrenia. J Clin Psychiatry. 2007;68(4):597-603. 